\title{
Index to Volume 38 (2011)
}

No. 1, pp. 1-76; No. 2, pp. 77-175; No. 3, pp. 177-280;

No. 4, pp. 281-364; No. 5, pp. 365-460; No. 6, pp. 461-540.

\section{ALPHABETICAL INDEX}

\subsection{Articles}

Almeida, Mauricio, Renato Souza, and Fred

Fonseca. Semantics in the Semantic Web:

A Critical Evaluation

An, Lu, Jin Zhang, and Chuanming Yu. The Visual Subject Analysis of Library and Information Science Journals with Self-Organizing Map . 299

Anizi, Mouna and Joseph Dichy. Improving Information Retrieval in Arabic through a Multi-agent Approach and a Rich Lexical Resource ........405 Benson, Allen C. OntoPhoto and the Role of Ontology in Organizing Knowledge..

Bernaoui, Radia and Mohamed Hassoun. Knowledge Awareness and Standards in Agricultural Research in Algeria: Prerequisites for a National Information System of High Added Value......414 Blake, James. Some Issues in the Classification of Zoology

Bounhas, Ibrahim, Bilel Elayeb, Fabrice Evrard, and Yahya Slimani.

Organizing Contextual Knowledge for Arabic

Text Disambiguation and Terminology Extraction

Bouramoul, Abdelkrim. The Semantic Dimension in Information Retrieval, from Document Indexing to Query Reformulation ....

Buchel, Olha and Kamran Sedig. Extending Map-Based Visualizations to Support Visual Tasks: The Role of Ontological Properties

Feinberg, Melanie. Expressive Bibliography:

Personal Collections in Public Space

Fox, Melodie J. Prototype Theory: An

Alternative Concept Theory for Categorizing

Sex and Gender?

Frické, Martin. Faceted Classification:

Orthogonal Facets and Graphs of Foci?.

Giménez-Chornet, Vicent, and Mercedes

Escrig-Giménez. Designing a Thesaurus to

Give Visibility to the Historical Archives in the Archivo del Reino in Valencia

Golub, Koraljka. Automated Subject Classification of Textual Documents in the Context of Web-Based Hierarchical Browsing.

Green, Rebecca. See-also Relationships in the Dewey Decimal Classification.

Hudon, Michèle. Teaching Classification in the $21^{\text {st }}$ Century
Kaipainen, Mauri and Antti Hautamäki. Epistemic Pluralism and Multi-Perspective Knowledge Organization: Explorative Conceptualization of Topical Content Domains

Kipp, Margaret E.I. Tagging of Biomedical

Articles on CiteULike: A Comparison of User, Author and Professional Indexing.

Lee, Deborah. Classifying Musical Performance: The Application of Classification Theories to Concert Programmes .

Lee, Hur-Li and Wen-Chin Lan. Proclaiming Intellectual Authority Through Classification: The Case of the Seven Epitomes

López Piñeiro, Carla and Elea Giménez Toledo. Knowledge Classification: A Problem for Scientific Assessment in Spain?

Mai, Jens-Erik. Folksonomies and the

New Order: Authority in the Digital Disorder

McTavish, Jill R., Diane Rasmussen Neal, and

C. Nadine Wathen. Is What You See What You Get? Medical Subject Headings and their Organizing Work in the Violence Against Women Research Literature

Melgar Estrada, Liliana M. Topic Maps from

a Knowledge Organization Perspective

Paling, Stephen. Developing a Metadata Element Set for Organizing Literary Works: A Survey of the American Literary Community

Park, Heejin. A Conceptual Framework to Study Folksonomic Interaction.

Pattuelli, M. Cristina. Mapping People-centered Properties for Linked Open Data

Petric , Karl, Teodor Petric , Marjan Krisper, and

Vladislav Rajkovic . User Profiling on a Pilot

Digital Library with the Final Result of a New

Adaptive Knowledge Management Solution

Rafferty, Pauline. Informative Tagging of Images:

The Importance of Modality in Interpretation ....

Shiri, Ali. Revealing Interdisciplinarity in

Nanoscience and Technology Queries:

A Transaction Log Analysis Approach

Søilen, Klaus Solberg and Philip Baback Alipour.

Semantics, Classifications and Evidence in a Model

for Global Catastrophic Risks.

\subsection{Book Reviews}

Biagetti, Maria Teresa, ed. Le ontologie.

AIDAinformazioni 28 (2010), n. 1-2.

ISSN 1121-0095 
Gilchrist, Alan, ed. Information Science in Transition. London: Facet Publishing, 2009. Xxix, 401 pages. ISBN 978-1-85604-693-0 .171

O'Connor, Brian C., Jodi Kearns, and Richard L. Anderson. Doing Things with Information: Beyond Indexing and Abstracting. Westport, Connecticut: Libraries Unlimited, 2008. xix, 241 pages. ISBN: 987-1-59158-577-0

Miller, Joseph, ed. Susan McCarthy, assoc. ed. Sears List of Subject headings - 20th ed. New York; Dublin: The H.W Wilson Co, 2010, liii, 847p. ISBN 978-0-8242-1105-9 (Hb)

\subsection{Reports, Communications, Features, etc.}

Channon, Martin.The Stowe Table as the Definitive Periodic System .321

Cooper, Rachel. Some Classifications Will be Natural.....
Dahlberg, Ingetraut. How to Improve ISKO's Standing: Ten Desiderata for Knowledge Organization .68

Dupré, John. A Note on the Debate Between Hjørland and Scerri on the Significance of the Periodic Table 9

Hjørland, Birger. The Periodic Table and the Philosophy of Classification .9

Mazzocchi, Fulvio. Kinds, Classification and Realism ....

Scerri, Eric. What is the Nature of the Periodic Table as a Classification System? .9

Smiraglia, Richard P.I Simposio Internacional sobre Organizacion del Conocimiento,

Bibliotecologia y Terminologia: An Editorial .3

Smiraglia, Richard P. ISKO 11's Diverse Bookshelf: An Editorial... 


\title{
KNOWLEDGE ORGANIZATION
}

\author{
Official Bi-Monthly Journal of the International Society for Knowledge Organization \\ ISSN $0943-7444$ \\ International Journal devoted to Concept Theory, Classification, Indexing and Knowledge Representation
}

\author{
Publisher \\ ERGON-Verlag GmbH, Keesburgstr. 11, D-97074 Würzburg \\ Phone: +49 (0)931 280084; FAX + 49 (0)931 282872 \\ E-mail: service@ergon-verlag.de; http://www.ergon-verlag.de
}

\section{Editor-in-chief (Editorial office)}

Dr. Richard P. SMIRAGLIA (Editor-in-Chief), Palmer School of Library and Information Science, Long Island University, 720 Northern Blvd., Brookville NY 11548 USA.

Email: Richard.Smiraglia@liu.edu

\section{Instructions for Authors}

Manuscripts should be submitted electronically (in Word or RTF format) in English only via email to the editor-in chief and should be accompanied by an indicative abstract of 100 to 200 words.

A separate title page should include the article title and the author's name, postal address, and E-mail address, if available. Only the title of the article should appear on the first page of the text.

To protect anonymity, the author's name should not appear on the manuscript, and all references in the body of the text and in footnotes that might identify the author to the reviewer should be removed and cited on a separate page. Articles that do not conform to these specifications will be returned to authors.

Criteria for acceptance will be appropriateness to the field of the journal (see Scope and Aims), taking into account the merit of the contents and presentation. The manuscript should be concise and should conform as much as possible to professional standards of English usage and grammar. Manuscripts are received with the understanding that they have not been previously published, are not being submitted for publication elsewhere, and that if the work received official sponsorship, it has been duly released for publication. Submissions are refereed, and authors will usually be notified within 6 to 10 weeks.

The text should be structured by numbered subheadings. It should contain an introduction, giving an overview and stating the purpose, a main body, describing in sufficient detail the materials or methods used and the results or systems developed, and a conclusion or summary.

Footnotes are not permitted; all narration should be included in the text of the article.

Italics should not be used for emphasis. Em-dashes should be used as substitutes for commas. Paragraphs should include a topic sentence and some developed narrative. A typical paragraph has several sentences.

Reference citations within the text should have the following form: (author year). For example, (Jones 1990). Specific page numbers are required for quoted material, e.g. (Jones 1990, 100). A citation with two authors would read (Jones and Smith, 1990); three or more authors would be: (Jones et al., 1990). When the author is mentioned in the text, only the date and optional page number should appear in parenthesis - e.g. According to Jones (1990), ...

References should be listed alphabetically by author at the end of the article. Author names should be given as found in the sources (not abbreviated). Journal titles should not be abbreviated.
Multiple citations to works by the same author should be listed chronologically and should each include the author's name. Articles appearing in the same year should have the following format: "Jones 2005a, Jones 2005b, etc." Issue numbers are given only when a journal volume is not through-paginated.

Examples:

Dahlberg, Ingetraut. 1978. A referent-oriented, analytical concept theory for INTERCONCEPT. International classification 5: $142-51$.

Howarth, Lynne C. 2003. Designing a common namespace for searching metadata-enabled knowledge repositories: an international perspective. Cataloging $E$ classification quarterly 37n1/2: 173-85.

Pogorelec, Andrej and Šauperl, Alenka. 2006. The alternative model of classification of belles-lettres in libraries. Knowledge organization 33: 204-14.

Schallier, Wouter. 2004. On the razor's edge: between local and overall needs in knowledge organization. In McIlwaine, Ia C. ed., Knowledge organization and the global information society: Proceedings of the Eighth International ISKO Conference 13-16 July 2004 London, UK. Advances in knowledge organization 9. Würzburg: Ergon Verlag, pp. 269-74.

Smiraglia, Richard P. 2001. The nature of 'a work': implications for the organization of knowledge. Lanham, Md.: Scarecrow.

Smiraglia, Richard P. 2005. Instantiation: Toward a theory. In Vaughan, Liwen, ed. Data, information, and knowledge in a networked world; Annual conference of the Canadian Association for Information Science ... London, Ontario, June 2-4 2005. Available http://www.cais-acsi.ca/2005proceedings.htm.

Illustrations should be kept to a necessary minimum and should be embedded within the document. Photographs (including color and half-tone) should be scanned with a minimum resolution of $600 \mathrm{dpi}$ and saved as .jpg files. Tables and figures should be embedded within the document. Tables should contain a number and title at the bottom, and all columns and rows should have headings. All illustrations should be cited in the text as Figure 1, Figure 2, etc. or Table 1, Table 2, etc.

Upon acceptance of a manuscript for publication, authors must provide a wallet-size photo and a one-paragraph biographical sketch (fewer than 100 words). The photograph should be scanned with a minimum resolution of $600 \mathrm{dpi}$ and saved as a .jpg file.

\section{Advertising}

Responsible for advertising: ERGON-Verlag GmbH, Keesburgstr. 11, 97074 Würzburg (Germany).

(C) 2012 by ERGON-Verlag GmbH.

All Rights reserved.

KO is published bi-monthly by ERGON-Verlag GmbH.

- The price for the print version is $€ 198,00$ /ann. including airmail delivery.

- The price for the print version plus access to the online version (PDF) is $€ 229,00 / a n n$. including airmail delivery. 


\title{
$\mathrm{KO}$
}

\section{KNOWLEDGE ORGANIZATION}

\author{
Official Bi-Monthly Journal of the International Society for Knowledge Organization \\ ISSN $0943-7444$ \\ International Journal devoted to Concept Theory, Classification, Indexing and Knowledge Representation
}

\section{Scope}

The more scientific data is generated in the impetuous present times, the more ordering energy needs to be expended to control these data in a retrievable fashion. With the abundance of knowledge now available the questions of new solutions to the ordering problem and thus of improved classification systems, methods and procedures have acquired unforeseen significance. For many years now they have been the focus of interest of information scientists the world over.

Until recently, the special literature relevant to classification was published in piecemeal fashion, scattered over the numerous technical journals serving the experts of the various fields such as:

\author{
philosophy and science of science \\ science policy and science organization \\ mathematics, statistics and computer science \\ library and information science \\ archivistics and museology \\ journalism and communication science \\ industrial products and commodity science \\ terminology, lexicography and linguistics
}

Beginning in 1974, KNOWLEDGE ORGANIZATION (formerly INTERNATIONAL CLASSIFICATION) has been serving as a common platform for the discussion of both theoretical background questions and practical application problems in many areas of concern. In each issue experts from many countries comment on questions of an adequate structuring and construction of ordering systems and on the problems of their use in opening the information contents of new literature, of data collections and survey, of tabular works and of other objects of scientific interest. Their contributions have been concerned with

(1) clarifying the theoretical foundations (general ordering theory/science, theoretical bases of classification, data analysis and reduction)

(2) describing practical operations connected with indexing/classification, as well as applications of classification systems and thesauri, manual and machine indexing

(3) tracing the history of classification knowledge and methodology

(4) discussing questions of education and training in classification

(5) concerning themselves with the problems of terminology in general and with respect to special fields.

\section{Aims}

Thus, KNOWLEDGE ORGANIZATION is a forum for all those interested in the organization of knowledge on a universal or a domain-specific scale, using concept-analytical or concept-synthetical approaches, as well as quantitative and qualitative methodologies. KNOWLEDGE ORGANIZATION also addresses the intellectual and automatic compilation and use of classification systems and thesauri in all fields of knowledge, with special attention being given to the problems of terminology.

KNOWLEDGE ORGANIZATION publishes original articles, reports on conferences and similar communications, as well as book reviews, letters to the editor, and an extensive annotated bibliography of recent classification and indexing literature.

KNOWLEDGE ORGANIZATION should therefore be available at every university and research library of every country, at every information center, at colleges and schools of library and information science, in the hands of everybody interested in the fields mentioned above and thus also at every office for updating information on any topic related to the problems of order in our information-flooded times.

KNOWLEDGE ORGANIZATION was founded in 1973 by an international group of scholars with a consulting board of editors representing the world's regions, the special classification fields, and the subject areas involved. From 1974-1980 it was published by K.G. Saur Verlag, München. Back issues of 1978-1992 are available from ERGON-Verlag, too.

As of 1989, KNOWLEDGE ORGANIZATION has become the official organ of the INTERNATIONAL SOCIETY FOR KNOWLEDGE ORGANIZATION (ISKO) and is included for every ISKO-member, personal or institutional in the membership fee (US \$ 55/US \$ 110).

Rates: From 2011 on for 6 issues/ann. (including indexes) $€ 198,00$ (forwarding costs included) for the print version resp. $€ 229,00$ for the print version plus access to the online version (PDF). Membership rates see above.

ERGON-Verlag GmbH, Keesburgstr. 11, D-97074 Würzburg; Phone: +49 (0)931 280084; FAX +49 (0)931 282872; E-mail: service@ergon-verlag.de; http://www.ergon-verlag.de

The contents of this journal are indexed and abstracted in Referativnyi Zhurnal Informatika and in the following online databases: Information Science Abstracts, INSPEC, Library and Information Science Abstracts (LISA), Library Literature, PASCAL, Sociological Abstracts, and Web Science \& Social Sciences Citation Index. 


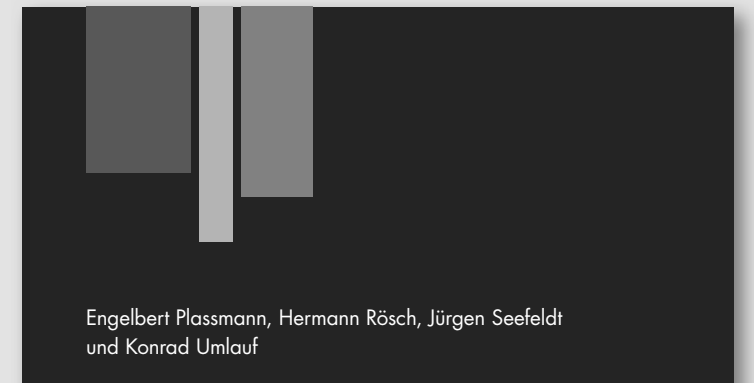

Bibliotheken

und Informationsgesellschaft

in Deutschland

\section{Eine Einführung}

2., gründlich überarbeitete und erweiterte Auflage

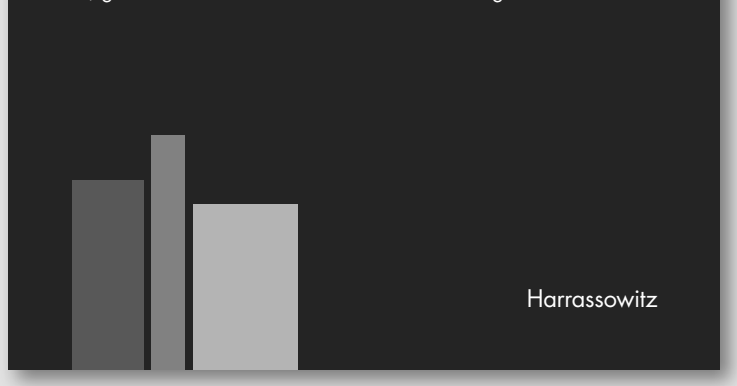

In der Einführung Bibliotheken und Informationsgesellschaft in Deutschland wird das deutsche Bibliothekswesen der Gegenwart erstmals nicht aus bibliothekarischer Binnensicht, sondern aus gesamtgesellschaftlicher Perspektive dargestellt. Aus diesem Blickwinkel heraus werden Leistungen und Funktionen der Bibliotheken analysiert und bewertet. Die Autoren aus Forschung und Praxis beobachten historische Entwicklungslinien, beschreiben aktuelle Trends und zeigen Handlungsoptionen auf. Dabei gehört zu den Veränderungen im Bibliothekswesen neben Funktionsveränderungen und systemischer Vernetzung auch die Möglichkeit der Annäherung an andere Bereiche des Informationswesens oder gar die Konvergenz mit innen. Die 2. Auflage wurde gründlich überarbeitet und durchgängig aktualisiert. Einige Kapitel wurden in Teilen neu gefasst, um Entwicklungen wie Bibliothek 2.0, Semantic Web, Linked Open Data oder Electronic Resource Management zu berücksichtigen.
Aus dem Inhalt:

Historische und soziologische Entwicklungslinien in den Bereichen Bibliothek, Archiv, Dokumentation, Informationspraxis, Medien - Strukturelle und technische Entwicklungslinien - Vom segmentär zum funktional differenzierten Bibliothekssystem - Hybride, digitale und virtuelle Bibliotheken - Bibliotheken in öffentlicher, privater und kirchlicher Trägerschaft

Bibliothekstypologie - Netze und Kooperationen, Innovationen und Projekte Normen und Standards, Richtlinien und Empfehlungen - Informationsdienstleistungen, Informations- und Auskunftsdienst, bibliothekarisches Wissensmanagement - Bibliotheksmanagement - Beruf, Ausbildung, Studium - Perspektiven der Bibliothek, Chancen und Restriktionen

2011. XII, 388 Seiten, 47 Tabellen 6 Karten, br

ISBN 978-3-447-06474-3

$€ 34,80$ (D)
HARRASSOWITZ Verlag

\section{Bibliothek und Wissenschaft}

44 (2011)

Digitale Edition und Forschungsbibliothek

Beiträge der Fachtagung im Philosophicum der Universität Mainz am 13. und 14. Januar 2011

2011. VI, 186 Seiten, br

ISBN 978-3-447-06568-9

€ 99,- (D)

Christine Haug, Vincent Kaufmann ( $\mathrm{Hg}$.)

\section{Kodex 1 (2011)}

Die digitale Bibliothek

2011. Ca. 240 Seiten, br

ISBN 978-3-447-06485-9

Ca. $€ 39,80$ (D)

Elke Blumenthal, Wolfgang Schmitz (Hg.)

\section{Bibliotheken im Altertum}

Wolfenbütteler Schriften zur Geschichte des Buchwesens 45

2011. 270 Seiten, 33 Abb., gb ISBN 978-3-447-06406-4 $€ 79,-(D)$

Michael Knoche, Wolfgang Schmitz (Hg.)

Wissenschaftliche Bibliothekare im Nationalsozialismus

Handlungsspielräume, Kontinuitäten, Deutungsmuster

Wolfenbütteler Schriften zur Geschichte des Buchwesens 46

2011. 381 Seiten, 14 Abb., gb

ISBN 978-3-447-06407-1

$€ 89,-(D)$

Klaus Haller, Klaus Kempf (Hg.)

\section{Sammeln und Erwerben}

\section{an der Bayerischen}

\section{Staatsbibliothek}

In Memoriam Emil Gratzl (1877-1957)

Schriftenreihe der Bayerischen Staatsbibliothek 4

2011. 171 Seiten, 10 Abb.,

1 Tabelle, Frontispiz, gb

ISBN 978-3-447-06641-9

Ca. $€ 48,-(D)$ 